\title{
FACTORS INFLUENCING HOUSEHOLDS' PARTICIPATION IN FOREST MANAGEMENT IN THE NORTHERN REGION OF GHANA
}

\author{
Jamal Mohammed \\ Faculty of Business and Management Studies, \\ Koforidua Technical University, Ghana \\ E-mail: jamalmohammed@ktu.edu.gh
}

Anthony Kofi Osei-Fosu Kwame Nkrumah University of Science and Technology, Ghana E-mail: akosei-fosu.cass@knust.edu.gh

Hadrat Yusif Kwame Nkrumah University of Science and Technology, Ghana E-mail: hadraty@yahoo.co.uk

Submission: 09/02/2017

Revision: 20/03/2017 Accept: 11/05/2017

\section{ABSTRACT}

This study assessed the factors influencing households' participation in forest management. The specific objective was to identify the determinants of households' participation in forest management in the Northern Region of Ghana. The study used the cluster random sampling to sample the six (6) communities out of nine (9) communities within the Tamale forest districts and purposively interviewed respondents from these communities. The sample size was three hundred and seventy (370). The logistic regression analysis result showed that, sex, age, household size, education, benefit and location of the forest positively influenced households' participation in forest management. The results showed that, all the aforementioned sociodemographic characteristics of the respondents were significant in determining participation in forest management. The study recommended that the government of Ghana should intensify awareness creation and public education on the need for collaborative forest management between local communities and forest management staff. 
INDEPENDENT JOURNAL OF MANAGEMENT \& PRODUCTION (IJM\&P)

http://www.ijmp.jor.br

v. 8, n. 4, October - December 2017

ISSN: 2236-269X

DOI: 10.14807/ijmp.v8i4.631

Keywords: Households Participation, Forest Management, Logistic Regression

\section{INTRODUCTION}

Sustainable harvest of forests by households and other forest users is seen as the surest way of maintaining forest growth level worldwide. Local communities' livelihood as main driver for dependence on forest and at the same time increased population dependence have prompted world leaders, nations and local communities to integrate sustainable livelihood approach to saving the forest and also to reduce deforestation and environmental degradation.

The anticipated negative effects of deforestation, environmental degradation, climate change and global warming is a worldwide phenomenon without recourse to country specific (KAPINGA, 2015).

Bhusal (2014) reported that Reducing Emission from Deforestation and Forest Degradation, Conservation of existing forest carbon and Enhancement of forest carbon through sustainable forest management (REDD+) mechanisms and policies as proposed by the United Nations is an important step puts forth to reduce greenhouse gas emission and enhance forest carbon storage capacity.

Onyekuru (2014) indicated that the developing countries, especially those in Africa, are forecast to be the worst to be impacted by the anticipated negative effects of the global environmental change. This view is collaborated by IPCC (2014) study cited in Onyekuru (2014) that Africa warmed by approximately $0.7^{\circ} \mathrm{C}$ during the 20th Century with a reduced rainfall intensively hovering over large portions of the Sahel.

Population growth in Africa is increasing (United Nations Population Division, 2013). This increased population growth is applicable in Ghana and Northern Region (GBOGBO, 2011; GSS, 2010). The increase in population growth is likely to be associated with: a higher than the global average degree of change, high levels of dependence on natural resources and forest goods and services, and a relatively low degree of adaptive capacity (EASTAUGH, 2010 cited in KAPINGA, 2015).

Increases in human population is likely to increase household size and this could lead to increase in fuel wood dependence in Ghana and other developing countries. Kapinga (2015) argued that, the majority of these households who depend on the forest for their livelihood are from the rural periphery of the developing countries and this has led to deforestation as a common feature. 
INDEPENDENT JOURNAL OF MANAGEMENT \& PRODUCTION (IJM\&P)

http://www.ijmp.jor.br

v. 8, n. 4, October - December 2017

ISSN: 2236-269X

DOI: 10.14807/ijmp.v8i4.631

The urban centres in developing countries have served as market channels for fuel wood demand and thus aggravates and fuels high dependency rate (MOHAMMED; OSEI-FOSU, 2016). Knight and Rosa (2012) suggest that household size has become a dominant issue in socio-ecological literature because of the important role demographic variables play in any societal set up.

While the household heavily depends on the forest for fuel wood because of the size of the household, the participation and level of management by households, communities in relation to forests have been a subject of considerable debate in the literature.

Hagen (2014) indicated that management of community forestry, with clear cut policies, governance and programmes, and which are supported by the local communities, has proven to be more successful compared with those without community involvement even with good policies.

Rodgers (2012) showed that, successful community forestry programmes have provided impetus for REDD+, as regards best practices for forest governance and thus reduces deforestation and forest degradation. In addition, the factors which influence households' participation should be thought through properly.

Indeed, the Government of Ghana has recognized the contribution of the forest in terms of income/ livelihoods of rural peoples, particularly fuel wood dependence and the role any policy will impact on these people.

Damptey and Essel (2012) provide an account that traditionally Ghana has been a tropical climate, with the southeast coast comparatively warm and dry, whereas the southwest is hot and humid and the north is hot and dry. This could be the consequences of climate change in Ghana and other African countries and result in erratic rainfall patterns, major flooding, rising sea levels, hot weather condition, especially in the northern Ghana.

Unfortunately, Ghana and other Sub-Saharan Africa (SSA) countries have contributed little to the global climate change unlike the major polluters like China, US and India (LEGGETT, 2011). But are likely to suffer most from the effects of continuing climate change.

The Northern Region has twenty four (24) forest reserves and these serve the needs of communities (SAVANNAH FORESTRY DIVISION, 2008). Individuals and 
INDEPENDENT JOURNAL OF MANAGEMENT \& PRODUCTION (IJM\&P)

http://www.ijmp.jor.br

v. 8, n. 4, October - December 2017

ISSN: 2236-269X

DOI: 10.14807/ijmp.v8i4.631

communities close to these forests are to collaborate with forest management to safeguard the forests. However, often there exists conflicts between forests management and local communities and these conflicts are as a result of the degree of forest dependence by individuals.

This hampers collaborative forests management between local communities and forests managers at the local level. What drives local community members towards participation and collaborative forests management at the local level has been a considerable debate.

Households receive huge amounts of benefit from forests within their catchment area. Any policy which is to hinder the benefit that they receive from the forest would attract resistance. In addition, given the important role of active participation of households' towards community forest management in the Northern Region of Ghana, the major factors influencing households participation becomes a greater task for policy makers.

The main goal of the study was to assess the factors influencing households' participation in forest management in the Northern Region of Ghana. The study proposes to: identify the determinants of households' participation in the forest management in the Northern Region of Ghana.

The research question is: what are the determinants which affect households' participation in the forest management in the Northern Region of Ghana? The study hypothesises that: households' participation in forest management is not influenced by the location of the forest to the communities.

Damptey and Essel (2012) have argued that traditional knowledge has been the first form of knowledge to engineer coping to climate change consequences related to over exploitation of the forest at the local level; a more pragmatic knowledge based systems is required to reduce the more severe burden of climate change through the reduction in asymmetric information between households and government forest managers.

The study is significant in that information obtained from this study can provide ways for policy makers to identify a collaborative approach to saving the forest while still allowing for some amount of fuel wood dependence. 
DOI: 10.14807/ijmp.v8i4.631

\subsection{Theoretical Literature Review}

This study reviewed theoretical literature related to the objective of the study to offer insight into the factors which influence households' participation in forest management in the Northern Region of Ghana.

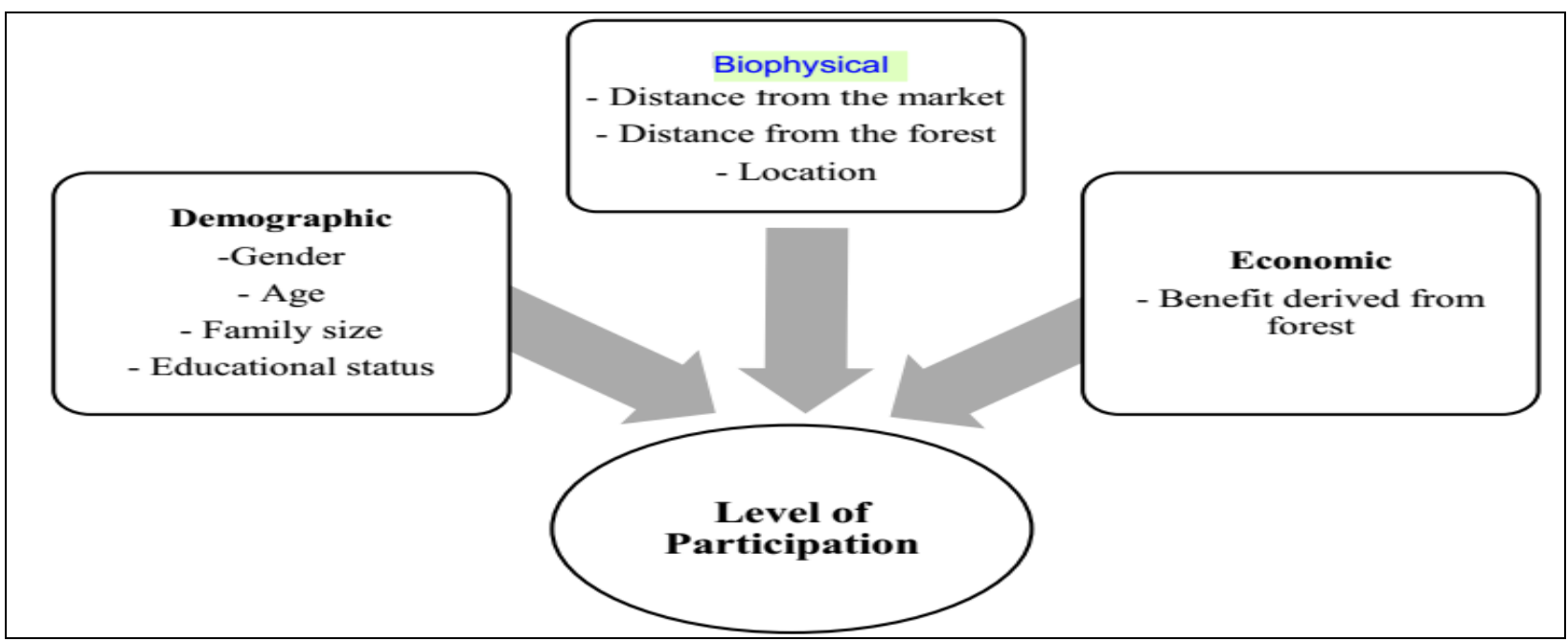

Figure 1: Schematic Presentation of the theoretical framework Source: Engida and Mengistu (2013)

The level of participation by the community and households in community forest management is hinged on the biophysical, demographic and economic dimension of the populace as illustrated in 1.

\subsection{Households Participation in Forest Management and Determinants}

Many community level forests are open access with issues on property rights and level of participation. Engida and Mengistu (2013) explained that the attempts at correcting the challenges of open and common access resources are imbued in collective action and as such directed towards common goal achievements.

Bray et al. (2002) cited in Meshack et al. (2006) reported that Communitybased forest management (CBFM) could be a pathway to promoting a win-win situation in forest management strategies while still maintaining some amount of benefits received by communities from the forests and also guaranteeing a functioning ecosystem and maintenance of forest cover.

Aabeyir et al. (2011) suggested that achieving sustainable woodland management and controlling and ensuring fuel wood collection in a sustainable way is viewed as a major challenge to Ghana's traditional energy sector. Perhaps, the 
INDEPENDENT JOURNAL OF MANAGEMENT \& PRODUCTION (IJM\&P)

http://www.ijmp.jor.br

v. 8, n. 4, October - December 2017

ISSN: 2236-269X

DOI: 10.14807/ijmp.v8i4.631

drivers of households' participation in community forest management are vital for sustainable fuel wood collection.

Empirical literature has explained some of the factors which influence households' participation in forest management and these factors are regional and location specific. Coulibaly-Lingani et al. (2011) assert that household members' participation in forest management is influenced to some extent by internal and external factors.

In addition, biophysical and economic factors have motivated households to participate in forest management. The household characteristics are seen as important variables which influence households' participation in forest management and are therefore considered in this current study.

\subsection{Households and Forest Degradation}

Deforestation and forest degradation have been a subject bothering many foresters, local, national and international bodies because of the important role of forest in ecosystem provisioning and maintenance. Actual drivers of forests degradation are often misunderstood by policy makers. Kissinger et al. (2012) indicate that the direct drivers of deforestation and forest degradation stem from both the actions and inactions of human interactions and these affect significant loss of forest cover and carbon stocks in the forests.

The quantification of deforestation and forest degradation is a difficult issue. The Intergovernmental Panel on Climate Change (IPCC) indicates that, the actual deforested estimates for tropical countries could not be accurately ascertained. Estimates have huge margins of error (WATSON et al., 2000 cited in FREDERIC et al., 2002)

Kissinger et al., (2012) postulate that households and forest users will continue to depend on the forest in the future. However, current levels of REDD+ incentives will not be enough to deal with the actual drivers of deforestation. While the REDD+ programme is supposed to provide a pathway by ensuring sustainable management of forests, efficiency in the fuel wood collection and a better institutional framework for countries are major factors which influence household's participation in forest management. Understanding these factors is crucial to determine how REDD+ initiative would be received by households. 
Damnyag (2012) reported that there are several major causes of loss of forest cover in Ghana and these include: wildfires, food crop farming, fuel wood harvesting, clearing of forests for cocoa, logging and infrastructure expansion. These causes of loss of forest cover are attributed to the action and inaction of households in Ghana; the Northern Region is no exception. There are many households which live around the Tamale Forest District and ascertaining their level of participation in forest management is considered a step in the right direction.

\subsection{Empirical Literature Review}

Engida, and Mengistu (2013) studied the determinants of community based forest management in Alamata, Ethiopia. Their objective was to assess the determinants of household participation level in community forest management. They focused on identifying the effects of demographic, bio-physical and economic factors on households' level of participation by way of using a logistic regression model.

The results showed that age, gender, level of education and family size were found to have a significant effect on the level of participation. From the biophysical view point, factors such as distance from the forest and location, a place where the respondents were located were found to correlate with the household's level of participation in community forest management (CFM). The household's economic benefit of forest was also found to be significant.

In addition, Kissinger et al. (2012) studied the drivers of deforestation and forest degradation which was a synthesis report for REDD+ Policymakers. They reported that REDD+ implementation, sustainability hinges on understanding the actual drivers of deforestation and changing the areas which are responsible greenhouse gas (GHG) emissions from forests. Their study brings to bear the significance of these drivers and how it impacts on REDD+ policy development and implementation.

They recommended that countries should continue to be involved in the climate change negotiations and in-country interventions to reduce deforestation and forest degradation. Their study provided a grounding for the significance of this 
INDEPENDENT JOURNAL OF MANAGEMENT \& PRODUCTION (IJM\&P)

http://www.ijmp.jor.br

v. 8, n. 4, October - December 2017

ISSN: 2236-269X

DOI: 10.14807/ijmp.v8i4.631

current study as households in the Northern Region of Ghana continue to depend on the forest for fuel wood.

Lastly, a study by Coulibaly-Lingani (2011) on factors influencing people's participation in the forest management program in Burkina Faso, West Africa has shown some relationship with the current study. Their study used a household survey of 165 members who belonged to forest management groups.

With the assistance of factor analysis and multiple regression procedures, they showed that gender, household size, income source, land tenure status and technical assistance were the factors which influenced household members' forest management participation. They suggested that forest management participation, which was equitable and gender sensitive, could improve participation in forest management.

\section{METHODOLOGY}

\subsection{Area of the Study}

This study was undertaken in the Northern region with special focus on the Tamale forest district. The savannah forest division (2008) reported that the Northern region has twenty-four (24) forest reserves, of which seventeen (17) are natural forests and seven (7) are reserves developed through Plantation. The districts in the Northern region of Ghana are categorized into five (5) forest districts, namely: Tamale, Yendi, Damango-Buipe, Walewale and Bole forest districts. Each forest district spans several politically administrative districts and serve the needs of the fringe households (HUSSEIN et al., 2015).

Hussein et al. (2015) reported that the Tamale forest district borders on three (3) major political districts which are Tamale Metropolitan Area, Tolon - Kumbungu District and the Savelugu - Nanton Districts. The Sinsablegini forest reserve is the only natural forest located in between Tugu and Labariga whereas Tamale fuel wood plantation, Kogni plantation, Tamale Water Works forest reserve, the Ghana Education Service plantation and the Agriculture Department plantation are all plantation reserves.

Purposively, the study considered the Tamale forest district. Among other reasons for the establishment of the Sinsablegini forest reserve in 1956 was for it to serve as a plantation for fuel wood similar to the role assigned to the Tamale fuel 
INDEPENDENT JOURNAL OF MANAGEMENT \& PRODUCTION (IJM\&P)

http://www.ijmp.jor.br

v. 8, n. 4, October - December 2017

ISSN: 2236-269X

DOI: 10.14807/ijmp.v8i4.631

wood plantation (Husseini et al., 2015). The communities bordering the Sinsablegini forest reserve are Zoborgo, Kulaa, Moya, Zakariyili, Chepsigu, Tugu and Labariga.

\subsection{Sample and Sampling Technique}

The target population was fringe households or households living closer to the Tamale Forest District. The study adopted a purposive sampling approach to select six (6) communities (Zoborgo, Kulaa, Tugu, Labariga, Kogni East and Kogni West) out of the nine (9) communities (Zoborgo, Kulaa, Moya, Zakariyili, Chepsigu, Tugu and Labariga and two communities, namely: Kogni East and Kogni West) living around the fringes of the Tamale forest district and also to elicit information from households living along the only natural forest reserve (Sinsanblegbini) and Tamale fuel wood plantation.

In addition, the Sinsanblegbini forest reserve was established to provide ecosystem services like reducing soil erosion, plantation for fuel wood, medicinal purpose, thatch for local housing and so on (HUSSEINI, 2015). Whereas the Tamale fuel wood plantation was a pilot programme for fuel wood harvest. These two forests are important to this study as the study aimed to determine the factors which influence the households' to participate in forest management.

Seventy (75) houses were selected from each of the six communities and respondents were purposively selected. Questionnaires were distributed to respondents in the six (6) selected communities in the proportion of seventy five (75) questionnaires to each community. In all, the questionnaires retrieved from each community were as follows: Zoborgo (60), Kulaa (73), Tugu (68), Labariga (58), Kogni East (57) and Kogni West (54). The households sampled were homogeneous in terms of income and education. In all, three hundred and seventy (370) were interviewed for this study.

\subsection{Technique for Data Analysis}

The study used structured questionnaires to elicit information from the respondents. The data were checked for errors and coded using SPSS IBM Version 20 for analysis. The analysis included the assembling of tables and a logistic regression analysis to determine factors which influenced households to participate in forest management in the Northern Region of Ghana. The primary data were elicited from June 2, 2016 to July 30, 2016. 


\section{MODEL SPECIFICATION}

In order to explain households' participation in the study area, a logistic regression model was used. The study regressed household's participation as a dependent variable as a function of the independent variables which are socioeconomic and demographic variables as explained in economic theory and experience. The choice of the logistic regression model is premised on the specification of the dependent variable as binary in nature and in outcome. This is whether selected individuals (household heads) decide to participate actively in forest management (coded 1) or did not participate actively in forest management (coded 0).

Dependent variable $=$ household's participation $\left\{\begin{array}{l}1=\text { participate } \\ 0=\text { not participate }\end{array}\right.$

Independent variables $=$ (socio-demographic characteristics $)$

Therefore, the probability of a household participating in forest management, $\operatorname{Pr}(Y ;=1)$ is a joint probability likelihood function evaluated at $X i \quad \beta$, where $X i$ is a matrix of independent variables and $\beta$ is the coefficient of the independent variable.

\subsection{Estimated Logistic model}

Following Tafere (2013), the estimated logistic regression model is as follows:

$$
H P F M=\beta 0+\beta 1 A G+\beta 2 S X+\beta 3 M S+\beta 4 E D+\beta 5 H S+\beta 6 B D+\beta 7 L O+\varepsilon
$$

Where HPFM- refers to Household Participation in Forest Management; AG Age of the individual (household head); SX - Sex of respondent; ED - Education of individual; HS - indicating the number of people in the household; BD - Benefit derived from the forest; LO - Is the location /place where the household lives close to the forest and MS - Marital status of respondents.

Participation in forest management has to do with the involvement of fringe forest community members and forest management in a collaborative decision towards protecting livelihood and forest functioning (MUSYOKI et al., 2016). Participation according Buttoud (1999) classifications included: auto-mobilization, functional, passive and active (COULIBALY-LINGANI et al., 2011).

In the case of auto-mobilisation, the stakeholders take centre stage in decision making and this could be providing relevant information to community 
INDEPENDENT JOURNAL OF MANAGEMENT \& PRODUCTION (IJM\&P)

http://www.ijmp.jor.br

v. 8, n. 4, October - December 2017

ISSN: 2236-269X

DOI: 10.14807/ijmp.v8i4.631

members. Whereas, in functional participation, decision making is 'double-edged' where community members contribute to discussions. In the case of active participation, decision making is 'bottom up' approach and involves direct involvement of community members and that of major players in the forestry sector. However, with passive participation, community members or participants are direct receivers of information without partaking in decision making (AGARWAL, 2001).

\subsection{Variable Coding}

The dependent variable individuals (Household Participation in Forest Management) (household heads) decide to participate actively in forest management (coded 1 ) or less actively forest management (coded 0). AG - Age of the individual (household head) is continuous variable; Sex of respondent is a categorical variable (takes, 0- female, 1 male); ED - formal educational status of individual (takes, 0- no formal education, 1- formal education); HS - indicating the number of people in the household is a continuous variable; BD - Benefit derived from the forest is a categorical variable (takes -0 . Not benefit; $1=$ Benefit); LO - Is the location /place where the household lives close to forest is a categorical variable (takes 0- no; 1yes) and MS - Marital status of respondents is a categorical variable (takes 0unmarried; 1 - married)

\subsection{Expectation}

The a prior expectations are that the age of the respondent should have a positive relationship with the household participation in forest management; sex and marital status of the respondents could have a positive or negative relationship with household participation in forest management; education, household size, benefit from the forest and location of the forest are expected to have a positive relationship with household participation in forest management.

\subsection{Results and Discussions}

This study discusses the results and findings as well as linkage to empirical literature. The first results relate to the sociodemographic characteristics of households within the selected communities under study, which is shown in Table 1. 
INDEPENDENT JOURNAL OF MANAGEMENT \& PRODUCTION (IJM\&P)

http://www.ijmp.jor.br

v. 8, n. 4, October - December 2017

ISSN: 2236-269X

DOI: 10.14807/ijmp.v8i4.631

Table 1: Sociodemographic characteristics of Households

\begin{tabular}{|c|c|c|c|c|}
\hline Variable & $\begin{array}{l}\text { Total } \\
\mathrm{n}=370 \\
\mathrm{n}(\%)\end{array}$ & $\begin{array}{l}\text { Participants in forest } \\
\text { management } \\
n=83\end{array}$ & $\begin{array}{l}\text { Non-participant in } \\
\text { forest management } \\
n=287\end{array}$ & P-value \\
\hline $\begin{array}{l}\text { Sex } \\
\text { Male } \\
\text { Female }\end{array}$ & $\begin{array}{l}146(39.5) \\
224(60.5)\end{array}$ & $\begin{array}{l}2(2.4) \\
81(97.6)\end{array}$ & $\begin{array}{l}144(50.2) \\
143(49.8)\end{array}$ & $<0.001$ \\
\hline Age & & $46.0 \pm 3.7$ & $39.8 \pm 6.9$ & $<0.001$ \\
\hline $\begin{array}{l}\text { Occupation } \\
\text { Semi-skilled } \\
\text { Unskilled } \\
\end{array}$ & $\begin{array}{l}111(30) \\
259(70)\end{array}$ & $\begin{array}{l}38(45.8) \\
45(54.2) \\
\end{array}$ & $\begin{array}{l}73(25.4) \\
214(74.6)\end{array}$ & $<0.001$ \\
\hline $\begin{array}{l}\text { Household } \\
\text { Size }\end{array}$ & & $4.3 \pm 1.6$ & $3.5 \pm 1.4$ & $<0.001$ \\
\hline $\begin{array}{l}\text { Education } \\
\text { No formal } \\
\text { Formal }\end{array}$ & $\begin{array}{l}277(74.9) \\
93(25.1)\end{array}$ & $\begin{array}{l}43(51.8) \\
40(48.1)\end{array}$ & $\begin{array}{l}234(81.5) \\
53(18.5)\end{array}$ & $<0.001$ \\
\hline $\begin{array}{l}\text { Monthly } \\
\text { Income }\end{array}$ & & $374.3 \pm 147.0$ & $316.5 \pm 153.5$ & $<0.002$ \\
\hline $\begin{array}{l}\text { Marital Status } \\
\text { Married } \\
\text { Unmarried }\end{array}$ & $\begin{array}{l}296(80) \\
74(20)\end{array}$ & $\begin{array}{l}79(95.2) \\
4(4.8)\end{array}$ & $\begin{array}{l}217(75.6) \\
70(24.4)\end{array}$ & $<0.001$ \\
\hline
\end{tabular}

Categorical data are presented as frequencies (outside parentheses) and percentage (inside parentheses). Continuous data are presented as mean \pm standard deviation.

Source: Field data, 2016

Table 1 summarises the results of demographic characteristics of selected households within Tamale Forest district based on those participating in the forest management and those not participating in the forest management. A total of three hundred and seventy (370) individuals were sampled. Females were 224 (60.5\%) and the male counterparts were 146 (39.5\%). Unskilled people were 259 (70\%) and semi-skilled were $111(30 \%)$. With regard to education, $277(74.9 \%)$ had no formal education while $93(25.1 \%)$ had formal education. Marital status identification showed those married were $296(80 \%)$ while those unmarried were $74(20 \%)$.

Individuals who participated in forest management were significantly $(p<$ 0.001 ) older (46.0 \pm 3.7 years), had a larger household size $(4.3 \pm 1.6)$ and earned a greater monthly income (Ghథ $374.3 \pm 147.0$ ) compared to the individuals who did not participate in forests management. The majority of the participants were females (81 (97.6\%)) and married (79(95.2\%)).

A slightly smaller minority of the respondents were illiterate (40(48.1\%)). From Table 1, it is evident that for all the socioeconomic characteristics there were statistically significant differences between participants and non-participants in forest management. This result is similar to other studies such as Ngang (2015) Tafere (2013) and Bwalya (2011). 


\subsection{Factors Influencing households' participation in forest management}

Participation supposed to be a two-way situation in the management of selected forests in the Tamale forest district. Forest managers are to collaborate with fringe communities. In some situations, conflicts do occur between these actors and these disrupt the smooth interactions between these stakeholders. There could be many factors influencing households' participation in forest management in these localities. Table 2 shows a summary of the results a multivariate logistic regression analysis to determine the factors which influence households' participation in forest management in the Tamale forest district.

Table 1: Results of the Multivariate Logistic Regression Analysis

\begin{tabular}{|l|l|l|l|l|}
\hline Variable & $\boldsymbol{\beta}$ & OR (95\% Cl) & SE & P-value \\
\hline Sex & 3.555 & $34.984(11.138-109.884)$ & 0.584 & $0.000^{*}$ \\
\hline Age & 0.151 & $1.163(1.100-1.230)$ & 0.028 & $0.000^{*}$ \\
\hline Education & 1.581 & $4.860(1.315-17.960)$ & 0.667 & $0.018^{*}$ \\
\hline $\begin{array}{l}\text { Household } \\
\text { Size }\end{array}$ & 0.658 & $1.931(1.318-2.831)$ & 0.195 & $0.001^{*}$ \\
\hline $\begin{array}{l}\text { Benefit from } \\
\text { forest }\end{array}$ & 1.115 & $3.050(1.035-8.990)$ & 0.552 & $0.043^{*}$ \\
\hline $\begin{array}{l}\text { Location of } \\
\text { forest }\end{array}$ & 2.648 & $1.071(1.019-1.265)$ & 0.674 & $0.000^{*}$ \\
\hline Marital Status & -1.660 & $0.190(0.059-0.612)$ & 0.597 & $0.005^{*}$ \\
\hline Constant & -13.942 & & 1.877 & 0.000 \\
\hline
\end{tabular}

$\mathrm{OR}=$ Odds Ratio; $\mathrm{Cl}=$ Confidence Interval; *Significant variables; SE= Standard Errors Source: Field data, 2016

Table 2 provides results of the multivariate logistic regression to determine the factors which influence households' participation in forest management. The odd ratio shows that age, sex, formal education status, household size, benefit from forest and location of forest were more than one (1). This means a change in any of these variables was more likely to influence household participation in forest management.

The odds ratio for age shows that older people were more likely to participate in forest management. The result for sex indicates that men were more likely to participate in forest management than women. Marital status indicated that married people were less likely to participate in forest management.

Larger household size was associated with the likelihood of participation in forest management. Respondents who derived benefits from the forest were more 
INDEPENDENT JOURNAL OF MANAGEMENT \& PRODUCTION (IJM\&P)

http://www.ijmp.jor.br

v. 8, n. 4, October - December 2017

ISSN: 2236-269X

DOI: 10.14807/ijmp.v8i4.631

likely to participate in forests management. The closer the location of the forest to the household the more likely respondent would participate in forest management.

The study of Tafere (2013) supports the findings of this current study in relation to age, household size, and location of the forest. However, his study differs with this current study in relation to sex (gender) in forest management.

The a prior expectation was that, age was to have a positive relationship with participation in forest management and this result was obtained from the data. With respect to sex, the expectation was that, it could be positive or negative, the result showed positive with participation in forest management. Education (formal education), household size, location and benefit were expected to have a positive relation with participation in forest management, and these results were obtained from the data.

The study rejected the null hypothesis postulated that, households' participation in forest management was not influenced by the location of the forest to the community. The study accepted the alternative hypothesis and that, the location of the forest influences households' participation in forest management. This result regarding the hypothesis is supported by both Alhassan (2010) and Lise (2000).

\subsection{Deforestation and Forest Degradation Awareness}

Loaiza et al. (2015) reported that deforestation and forest degradation could be reduced if enough insight is provided regarding forest dependence and income generation; at the same time integrated them well in livelihood approaches of rural community.

The results of study revealed that 222(60\%) of the households indicated there was no deforestation at all while $148(40 \%)$ believed deforestation existed. The majority 222(60\%) believed that deforestation could be stopped if policy encouraged forest management through community participation. In addition, as many as $296(80 \%)$ of the households have rated their access to the forest products to be reduced.

Interestingly, the majority of respondents, $259(70 \%)$ did not know the role of forest in climate change. What was obvious from the study was that 222(60\%) of the respondents would receive a compensation by payments or by alternative sources of livelihood to stop harvesting products from forest reserves. 


\section{CONCLUSIONS AND RECOMMENDATIONS}

The general objective of the study was to assess the factors influencing Households' Participation in Forest Management in the Northern Region of Ghana. The Specific objective was to: identify the determinants which affect household's participation in the forest management in the Northern Region of Ghana.

Households' participation in forest management in the Tamale forest district was shown to be influenced by sociodemographic characteristics of the respondents. This study involved a sample size of three hundred and seventy (370) respondents. The sociodemographic variables which were sex, age, household size, education, and marital status were all significant in influencing participation in forest management.

In addition, the results obtained from the logistic regression analysis showed that sex, age, household size, benefit and location of the forest were factors influencing households' participation in forest management in the Tamale forest district. Many households responded that deforestation was not going on even though they agreed that their access to the forest was being reduced. Yet they believed that, deforestation could stop if there was an active policy to encourage forest management through community participation.

It was obvious from the study that households were dependent on the forest for resources with the harvest of fuel wood given a special focus as it contributed to their energy needs. The current arrangement of the management of the forest was seen to be inefficient and households felt that they were marginalized and left out from getting a share of the benefits. Respondents in the study area did not see deforestation as an issue because of their dependence on the forest and would stop if there was an alternative livelihood source.

The study recommended that any government policy framework must incorporate the sociodemographic variables which were significant. These variables if they are carefully incorporated in policy formulation could influence households' participation in cooperative forest management to reduce deforestation and forest degradation in the study area. Public education in forest management, forest provision of carbon sinks and the need for community's participation could enhance sustainable forest and sustainable development. 
INDEPENDENT JOURNAL OF MANAGEMENT \& PRODUCTION (IJM\&P)

http://www.ijmp.jor.br

v. 8, n. 4, October - December 2017

ISSN: 2236-269X

DOI: 10.14807/ijmp.v8i4.631

\section{LIMITATION OF THE STUDY}

This particular study is limited in scope to the selected communities and also in terms of methodology. Therefore, this study does not lay claim to generalization of its findings. However, the results is generalized to the selected districts.

\section{REFERENCES}

AABEYIR, R.; QUAYE-BALLARD, J. A.; VAN -LEEUWEN, L. M.; ODURO, W. (2011) Analysis of Factors Affecting Sustainable Commercial Fuelwood Collection in Dawadawa and Kunsu in Kintampo North District of Ghana. The IIOAB Journal.

AGARWAL, B. (2001). Participatory exclusions, community forestry, and gender: an analysis for South Asia and a conceptual framework. World Development, n. 29, p. 1623-1648.

ALHASSAN, A. M. (2010) Analysis of Primary Stakeholders Participation in Forest Resources Management: The Case of the Krokosua Hills Forest Reserve, Ghana. College of Engineering Faculty of Chemical and Materials Engineering Department of Material Engineering, MSC Thesis, Kwame Nkrumah University of Science and Technology, Kumasi.

BHUSAL, Y. (2014) Local livelihoods community Forestry and The REDD+; A case study of a REDD+ Project in Ludikhola watershed, Nepal. Department of International Environment and Development Studies, M.A Thesis.

BWALYA, S. M. (2011) Household Dependence on Forest Income in Rural Zambia. Zambia Social Science Journal, v. 2, n. 1.

COULIBALY-LINGANI, P.; SAVADOGO, P.; TIGABU, M.; PER-CHRISTER, O. (2011) Factors influencing people's participation in the forest management program in Burkina Faso, West Africa. Forest Policy and Economics, v. 13, p.292-302, Elsevier.

DAMNYAG, L. (2012) Valuation of ecosystem services for assessment of cost of deforestation, and analysis of its drivers with implications for sustainable forest management in Ghana. School of Forest Sciences, Faculty of Science and Forestry, University of Eastern Finland.

DAMPTEY, P. T. N.; ESSEL. A. K. (2012) Gender Perspectives of climate Change coping and Adaptive Strategies in Ghana.

ENGIDA, T. G.; MENGISTU, A. T. (2013) Explaining the Determinants of Community Based Forest Management: Evidence from Alamata, Ethiopia. International Journal of Community Development, v. 1, n. 2, p. 63-70, DOI:

$10.11634 / 233028791301431$.

GBOGBO, D. Y. (2011) Evaluation Of Population Census Data and Population Growth in Ghana through Demographic Analysis. Department of Mathematics, Kwame Nkrumah University of Science and Technology.

HUSSEINI, R.; BAATUUWIE, B.; ISSIFU, H. (2015) Natural forest reserves in the Northern region of Ghana: description and management status. Research journal's Journal of forestry, v. 2, n. 6. 
HUSSEINI. R. (unpublished data-2013) Community participation in Collaborative Management of Forest Reserves in the Northern Region of Ghana: PhD thesis Submitted to the Institute for Development (IDS), University of Cape Coast, GhanaJuly-2015.

KAPINGA, A. G. (2015) Impacts of REDD+ Activities to Rural Communities' Livelihood: Evidence from Kondoa Advancing REDD+ in KOLO Hills Forest Project in Tanzania, Morogoro, Tanzania.

KISSINGER, G.; HEROLD, M.; SY, V.. (2012) Drivers of Deforestation and Forest Degradation: A Synthesis Report for REDD+ Policymakers. Lexeme Consulting, Vancouver Canada.

LISE, W. (2000) Factors influencing people's participation in forest management in India. Ecological Economics, v. 34, p. 379-392, Elsevier.

LEGGETT, J. A. (2011) China's Greenhouse Gas Emissions and Mitigation Policies, Congressional Research Service.

LOAIZA, T.; NEHREN, U.; GEROLD, G. (2015) REDD+ and incentives: An analysis of income generation in forest-dependent communities of the Yasuní Biosphere Reserve, Ecuador. Applied Geography, n. 62, p. 225-236, Elsevier.

MESHACK, C. K.; AHDIKARI B.; DOGGORT, N.; LOVET, J. C. (2006) Transaction Costs of Community-based forest Management: empirical evidence from Tanzania. Afr. 3. ECol.3 tack well publishing limited.

MUSYOKI, J. K.; MUGWE, J.; MUTUNDU, K.; MUCHIRI, M. (2016). Factors influencing level of participation of community forest associations in management forests in Kenya, Journal of Sustainable Forestry, v. 35, n. 3, p. 205-216, DOI:10.1080/10549811.2016.1142454.

NGANG, F. D. (2015) The Contribution of Community-based Natural Resources Management to Livelihoods, Conservation and Governance in Cameroon. A comparative Assessment of three community forests in Fako Division. Thesis, Pan African Institute for Development-West Africa.

ONYEKURU, N. A. (2014) Assessing Climate Change Impacts and Indigeneous Adaptation Strategies on Forest Resource Use in Nigeria. Environment Department, University of York. PhD Thesis.

Watson, R. T. et al. (2000) Eds. Land Use, Land Use Changes and Forestry (Cambridge Univ. Press, Cambridge).

RODGERS, M. (2012) REDD+, Community Forestry and Gender: Lessons Learned and Paths Forward. Graduate School of Public and International Affairs, University of Ottana.

SAVANNAH FORESTRY AT A GLANCE (2008) Forestry Commission, Northern Region.

TAFERE, A. (2013) Factors affecting Forest User's Participation in Participatory Forest Management; Evidence from Alamata Community Forest, Tigrayi Ethiopia. Department of Management, College of Business and Economics, Mekelle University; M. A. Thesis.

UNITED NATIONS, Department of Economic and Social Affairs, Population Division (2013). World population prospects. 